\title{
«ТЕМНА ПРИРОДА» У БОГА ЯК ПРОБЛЕМА БОГОСЛОВСЬКО-ФІЛОСОФСЬКОЇ ТЕОДИЦЕЇ
}

\author{
O.С. Ухов
}

Хто прагне добра, повинен бути готовий терпіти зло. Іоан Дамаскін

Теодицея в історії філософської та богословської думки виступає одним із найскладніших питань. Проблемою «виправдання Бога» та узгодження «благого» і «розумного» Божественного управління світом з існуванням світового зла опікувалась чимала кількість філософів та богословів. Історичні форми теодицеї прямо залежали від уявлень людини про сутність Бога і його дій у світі. Як така теодицея набула свого сенсу за часів бурхливого розвитку християнської теології та християнської філософії. Богословська думка і філософія відповідають на одне питання (проблему теодицеї) виходячи кожна із специфіки свого дискурсу. Тому для нас дуже важливим і цікавим буде зіставлення двох різних, але в той же час схожих між собою поглядів щодо проблематики теодицеї. Також логічним для нашого аналізу даної проблеми буде спроба порівняти найкращі зразки теодицеї. Такими, з нашої точки зору, є теодицея Лейбніца, Шеллінга, Бердяєва, Августина Блаженного із залученням основного корпусу православної теології.

Витоком головних положень християнської теодицеї вважається Біблія. Біблія - як Старий Завіт, так і Новий Завіт - констатує недосконалість світу та існування в ньому зла. Проте у перших книгах Старого Завіту проблема теодицеї ледве намічається. Старозавітна людина не мала сумнівів у тому, що зло як таке не походить від Бога. Але на 
питання, чому змій протистояв Творцю і спокусив Адама, відповіді у Священному Писанні не дається. Панувала віра в абсолютну справедливість Бога, який допускає зло як відплату за гріхи. Проте вже у книзі Іова ми знаходимо гостре відображення проблеми теодицеї. Тут Бог відкидає різноманітні ідеї теодицеї друзів Іова. Бог приймає протести Іова, які більш наближені до істини, але і ця книга не дає в повній мірі відповіді на питання теодицеї. Іов примирюється з Богом, зустрівши Його лицем до лиця, в чому міститься натяк на неспроможність традиційних тлумачень загадки зла. Ця загадка не зводиться до відомих людині понять та уявлень. Проблема теодицеї вирішується повною довірою до Бога (приклад Іова), а не теоретичними побудовами. Навіть Новий Завіт не дає нам метафізичного уявлення про зло, а вчить лише як жити у світі, де панує зло, і як вести з ним боротьбу. Згідно з апостолом Іоанном, зло почалося не з людини, а з диявола (1 Ін 3:8). Як наслідок, зло укорінене в духовному світі і має духовні причини. Вперше про це йдеться в апокрифічній Книзі Еноха, де причиною падіння стало порушення волі Творця духовними істотами - ангелами, які діяли в супереч Його волі. В Новий час одна зі спроб тлумачення цього погляду належить Шеллінгу, ідеї якого в подальшому були розвинуті Бердяєвим. Так, російський філософ писав: «Проблема теодицеї вирішується лише свободою. Загадка зла є загадкою свободи. Без розуміння свободи не може бути зрозумілим ірраціональний факт існування зла у Божому світі» [2]. В тій чи іншій формі цю думку поділяє більшість християнських богословів.

Визнаючи той факт, що теологія не дає нам раціонального обгрунтування теодицеї, для нас цікавим залишається питання про те, в якій мірі філософ відстоюе богословську позицію у вирішенні проблеми існування у світі зла; а також - де знаходиться межа між богословською та філософською теодицеями? Другою проблемою для нас $\mathrm{e}$ питання про те, чому філософські аргументи щодо теодицеї не мають авторитетної сили в богословських побудовах? Почнемо з богословської аргументації. Сучасний православний богослов Ігумен Іларіон (Алфєєв) пише: «Зло не є початковою сутністю, яка одвічно співіснує і дорівнює Богу, воно є відпадіння від добра, боротьба з добром. В цьому сенсі воно взагалі не може бути названим „сутністю“, тому що не існує саме по собі. Як темрява або тінь не є самостійним буттям, а лише відсутністю світла, так зло є лише відсутністю добра» [5]. Думка сучасного богослова є підтвердженням скрізь віки позиції християнської теології в особі Афанасія Великого, Василя Великого, Григорія Ниського, Григорія Богослова, Климента Олександрійського, Ориге- 
на, Августина, Фоми Аквінського та ін. Зокрема, Василій Великий говорив, що «Зло не жива сутність, але стан душі, протилежний чесноті, і походить через відпадіння від добра. Тому не шукай зла зовні, не уявляй собі, що є якась первородна зла природа, але кожен хай визнає самого себе винуватцем своєї лихої вдачі» [4].

Отже, Бог не створив нічого злого: і ангели, і люди, і матеріальний світ - все це за природою є добрим і прекрасним. Проте розумним особистісним істотам (ангелам і людям) надана свобода волі, і вони спроможні спрямувати свою свободу проти Бога і таким чином породити зло. Водночас християнській богословській думці в історії доводилось зіштовхуватись з явними або прихованими проявами дуалізму, тобто такою філософською доктриною, згідно з якою у світі від початку діють дві різні сили - добро і зло, які керують світом і роздирають його навпіл - це маніхейство. За вченням маніхеїв, вся сукупність буття представляе собою два царства, які завжди існували разом: царство світла, яке наповнене безліччю добрих еонів (ангелів), і царство темряви, наповнене злими еонами (демонами). Богу світла підпорядкована вся духовна реальність, а бог темряви (сатана) володарює у матеріальному світі. Сама ж матерія є гріховною і злою субстанцією.

Християнська теологія відкидає вчення маніхеїв, тому що останні надавали злу самостійного існування, завдяки чому зло виправдовує себе у світі. Проте християнство і не може дати чіткої відповіді, чому саме Бог допускає зло у світі. Теологія зупиняється на тому, що зло керується Богом, що робить існування зла необхідною ланкою божественного устрою: «Бог абсолютно не причетний до зла, проте зло знаходиться під Його контролем, тому що саме Бог визначає межі, в яких зло може діяти. Більш того, за невідомими шляхами Свого Промислу, в педагогічних та інших цілях Бог іноді користується злом в якості знаряддя» [5]. Отже, ми маємо, з одного боку, абсолютну непричетність Бога до зла, а з іншого - опосередковану «невідомими шляхами» Божественного Промислу дію зла у світі. Чи може християнська свідомість задовольнятись цим протиріччям?

Звичайною відповіддю християнина $є$ наголос на свободі ангелів і людини. Саме завдяки свободі стає можливим існування зла. Проте істинна свобода можлива тільки в Богові; звідси - існування зла від самого початку, принаймні потенційно, припускається Творцем у Самому Собі. 3 іншого боку, Особистість Творця не може містити в Собі корінь зла. Ця антиномія вирішується вірою в те, що Бог не може бути причиною зла, або припущенням того, що в Богові $є$ щось таке, що не $є$ самим Богом. Цим другим шляхом пішла філософія в особі Шеллінга. 
Шеллінг у своїй праці «Philosophische Untersuchungen über das Wesen der menschlichen Freiheit und die damit zusammenhängenden Gegenstände» розділяє в Богові основу Його існування (природа Бога) і власне існування. Бог як дійсність самовиявляє Себе із прихованого стану (Божественної природи), ціллю якого є розум. Із темряви Своєї природи Бог породжує себе як найвищий розум, як Своє розумне відображення, що потенційно укорінене в темній основі. Таке самовиявлення є істинною єдністю Бога. Розділення такої єдності в людині породжує можливість добра і зла: «Якщо б у дусі людини тотожність обох начал була такою ж не розривною, як в Богові, то між Богом і людиною не було б різниці, тобто Бог не відкривав би Себе як Дух. Тому та єдність, яка в Богові нерозділена, повинна бути в людині розділеною - це і є можливістю добра і зла» [8, с. 111].

Таким чином, філософія має відповідь на питання: чому саме Бог дозволяє злу і дияволу діяти, і навіщо Він допускає зло? Там, де богословська думка завмирає, філософська шукає раціональної відповіді. Блаженний Августин визнавав, що він не в змозі відповісти на ці питання: «Я не можу проникнути в глибину цього рішення і визнаю, що воно перевищує мої сили» [5].

Шеллінг не погоджується з Августином і багатьма іншими отцями Церкви, а також з Лейбніцем у тому, що зло є суто негативним поняттям нестачі або відсутності добра. Німецький філософ вбачає у злі позитивну силу, яка спрямована проти сили добра. Шеллінг підтверджує це тим, що якби зло було тільки нестачею добра, то воно могло б виявлятись лише в найнікчемніших істотах. Він також стверджує, що зло стає можливим лише для досконалих істот (вочевидь Шеллінг не вважає гріховну дію, притаманну всім без винятку людям, проявом зла) і часто йде поруч з виявленням великих сил, як, наприклад, у диявола. «Однак, - говорить Шеллінг, - оскільки в добрі розумне начало, оскільки і начало світла, діє зовсім не саме по собі, а лише у зв'язку з самістю, тобто піднесене до духу, то і зло діє не із початку кінцевості для себе, приведеного у тісний зв'язок із центром темного начала, або начала самості; і оскільки існує ентузіазм добра, існує і натхнення зла» [8, с. 119-120]. Отже бачимо, що зло є ворожою по відношенню до Бога силою, але воно опосередковує можливість самовиявлення Творця. Зло, таким чином, стає необхідним, хоча і не розумним потенціалом, в процесі подолання Творцем Своєї протилежності (самого зла). Таким чином ми можемо припустити, що зло не дорівнює за своїми можливостями Богу, тобто дуалізм Шеллінга - не дорівнює маніхейському дуалізму. Отже спроба подолання філософом дуалізму робить можли- 
вим раціональне примирення християнської теології з філософією в питанні теодицеї.

Теодицея Шеллінга - не простий натуралістичний пантеїзм. Філософ у повній мірі усвідомлював проблематичність своєї позиції і вважав, що його пантеїзм $є$ необхідним підгрунтям для розвитку теїстичного світогляду. Теологія, яка починається з особистого Бога, дає поняття, яке не має підгрунтя і чітко визначеного змісту. Як наслідок, така теологія може бути лише теологією почуття та незнання. I навпаки, філософія тотожності виступає єдиним джерелом філософського Богопізнання, тому що вона дає доступні для розуму поняття Бога як Особистості, яка розвивається із Своєї першооснови. Теїзм неможливий, на думку Шеллінга, без розуміння живого особистого Бога, але розуміння живого Бога неможливе без розуміння Бога, що розвивається. Розвиток припускає природу, з якої Бог розвивається. Отже теїзм, за Шеллінгом, повинен мати своє обгрунтування в натуралізмі. Тобто натуралістичний пантеїзм є лише логічним припущенням на шляху до істинного розуміння християнської віри.

Загалом позиція Шеллінга стане більш зрозумілою, якщо ми поглянемо на те, як вирішувалась проблема теодицеї до нього.

Позиція деяких отців Церкви нам зрозуміла - зло є відсутністю добра і тенденцією до негації останнього. Проте вже у Діонісія Ареопагіта спостерігається наступний крок: «Чи не стає часто загибель одного народженням іншого? [.. . ] Зло бере участь в доповненні всього і доставляє собою цілому спроможність не бути незакінченим» [1]. Зло починає тлумачитись як відносне, як інший бік добра. Зло, таким чином, існує для того, щоб відрізняти добро і завдяки цій функції стає також задіяним у позитивному процесі добра. «Якщо ж зла немає, то чеснота і порок - одне й теж саме і в цілому, по відношенню до іншого цілого, і у співвідношеннях частин, і вже не буде злом те, що бореться з Добром» [там само].

Як бачимо, випадки припущення логічної необхідності існування зла мали місце в історії богословської думки. Про таку ж саме необхідність говорить і Шеллінг, шукаючи її обгрунтування.

Далі для нас цікавим буде порівняння позиції Августина Блаженного з поглядом Шеллінга. Для Августина зла як такого не існує. «Зло увійшло в світ із першим гріхом, з падінням людини, воно є результатом свобідної волі людини, яка добровільно обрала гріх. Спочатку в світі не було ніякого зла. Можливість такого падіння буття світу малась, проте, із самого творіння, бо світ не є Богом, тому світ і не може бути настільки ж досконалим як Творець» [3, с. 364]. Отже маємо у 
Августина припущення потенції зла, яка актуалізується в свободі волі людини. Можна також припустити, що, як і у Шеллінга, потенційність зла у Августина, ще не є злом самим по собі.

Шеллінг наголошує на тому, що умовним джерелом зла є темна природа в Богові. Їй протистоїть ідеальне начало в Богові або розум, в поєднанні цих двох начал і складається особистість Бога: «Оскільки в Богові є незалежна основа і тому два незалежних начала самоодкровення, то Бога в його свободі слід розглядати у відношенні до двох цих начал. Спочатку в творінні є прагнення єдиного породжувати самого себе, або воля основи.

Друге начало є воля любові, через яку в природу проголошується слово і через яку Бог тільки і робить себе особистістю» [8, с. 138-139]. Ідейне начало визначається в любові. Сліпа воля до самопородження і свобідна воля любові є головними діяльностями Бога, які об'єднуються в Його Особистості. Темна природа, оскільки вона в Богові, ще не $\epsilon$ злом. Вона стає злом лише в природі кінцевих речей, де вона не підпорядковується світлому началу і найвищій єдності.

Таким чином, зло лише попутно розвивається в самовизначенні Бога і коріниться в Його темній природі, але не може бути визнаним як акт Бога. «Однак неможна також стверджувати, що зло виходить 3 основи або що воля основи - джерело зла. Тому що зло може виникати лише в потаємній волі власного серця і ніколи не відбувається незалежно від власної дії людини. Збудження основи, або реакція на надтварне, породжує тільки потяг до тварного або власну волю, але пробуджує її лише для того, щоб була незалежна основа добра і щоб воля була подолана добром і проникнута ним. Незбуджена самість сама по собі є злом, але лише остільки, оскільки вона повністю відривається від своєї протилежності, від світла або універсальної волі. Саме ця відмова від добра і є гріхом» [8, с. 143]. Зло - зловживання силами Бога, які в Його Особистості є абсолютним добром. Об'єднання темного або стихійного та ідейного принципу в Богові відбувається завдяки любові у глибинній першооснові Творця, яка і є Його абсолютною Особистістю.

Слід відмітити, що подальша розробка проблеми теодицеї в історії філософської та богословської думки не була оригінальною. Ідеї Аврелія Августина розвиває Ансельм Кентерберійський, який вчив про те, що існують нескінченні ступені досконалості світу і злом є найнижча ступінь блага. Декарт також іде за Августином, проголошуючи, що недосконалість світу з необхідністю витікає із неможливості для Бога створити дещо настільки ж досконале, як і Він. Очевидно, що це 
найпростіше і логічне пояснення метафізичного зла, тобто іманентної світу можливості зла, містить один суттєвий недолік - воно постулює неможливість будь-чого для Бога.

Лейбніц, у свій час, фактично запропонував зняти проблему зла, оскільки ми не володіємо повними, Божественними знаннями про світ. Зло, за Лейбніцем, обов'язково приводить, у кінцевому рахунку, до добра - шляхи Господні несповідимі. I тут ми не знаходимо рішення. Лейбніц дотримується лінії своїх попередників і в цілому християнської теології, приписуючи Творцю лише потурання злу: «Внаслідок своєї вищої мудрості і великої благості він дотримується зі всією суворістю законів справедливості; [.. ] створює стільки щастя і чеснот, скільки може вмістити найкращий взірець універсуму, і допускає лише ті з пороків і зол, які необхідно було б допускати у найкращому ряді речей» $[6$, с. 488]. Зло реалізується волею людини: «І якщо те, чого він бажав, - пише про Бога Лейбніц, - не завжди здійснювалось, то це треба приписувати лише злобі і завзятості людей» [6, с. 489].

Однак теодицея Лейбніца сповнена протиріч. Всім монадам притаманна така якість, як мимовільність, спонтанність свободи, згідно $з$ якою «ми самі визначаємо себе до дії» [6, с. 324]. Проте монада Лейбніца абсолютно ізольована від усіх інших монад, але не від Бога. Бог не тільки творець кожної з монад, але й постійно її «зберігає», тобто безперервно створює, «подібно до променю, який безперервно виникає із сонця» $[6$, с. 325]. Бог не тільки передбачає «вільний» вчинок людини, але й зумовлює, напередвстановлює його, тобто створює монаду раз і назавжди. Будь-який «вільний» вчинок, що був вчинений «зараз», має розглядатись як творіння Боже. Бог творить все в монаді, а не співтворить з нею. Таким чином, немає власної волі, а є лише воля Бога. Монада вільна тільки по відношенню до іншої монади.

Як наслідок, у Лейбніца виділяються мова свободи і мова провидіння. Спроба їх поєднати призвела тільки до проголошення свободи, а на ділі, до її заперечення. Це заводить систему теодицеї у глухий кут, що усвідомлював і сам Лейбніц. Таким чином, можна стверджувати, що вирішити головну проблему теодицеї- проблему свободи, йому не вдалося.

З іншого боку, ніби передбачаючи Шеллінга, Лейбніц дорікає: «інші безоглядно висловлювали думку ніби те, що дурно в інших, зовсім не $є$ злом в Богові, тому що він не пов'язаний ні з яким законом» [6, с. 488].

Проте, на наш погляд, Шеллінг знімає протиріччя, які накопичились $з$ часів Августина, діалектично поєднуючи індетермінізм і детермінізм. Розглядаючи людину як образ Творця, Шеллінг вирішує 
проблему свободи раціоналізуючи, але не відходячи від християнськобогословського духу.

Він розділяє в людині особистість і природу - це повторює Бога як джерела образу. Людина, за Шеллінгом, йде шляхом Творця - маючи свободу, безперервно реалізує та актуалізує ㄲi. Зло представляє природне прагнення, спрямоване в бік, протилежний універсальній волі, i долається актом зречення власної індивідуальності. В цьому зреченні очищається людська воля, щоб стати до причетною універсальної волі Творця. Для перемоги над злом необхідно перш за все подолати в собі темне начало стихійної природи. Людина спроможна це зробити, і в цій спроможності актуалізується свобода.

Під свободою Шеллінг розуміє не випадкову можливість вибору у кожному даному випадку, а внутрішне самовизначення. Підгрунтям цього самовизначення є інтелігібельний характер, тобто те prius в людській особистості, яке від початку обумовлює людську конституцію і вчинки, що витікають 3 неї. Інтелігібельний характер є тим передвічним актом індивідуальної волі, яким визначаються інші її прояви. Первинна воля, яка лежить в основі інтелігібельного характеру, вільна, проте ті акти, в яких вона проявляється, йдуть один за одним з необхідністю і визначаються її первісною природою [8, с. 406]. Таким чином, у розвитку інтелігібельного характеру поєднується свобода з необхідністю. Провина людини в тому злі, яке вона виявляє, полягає не стільки в їі свідомих діях, скільки у передсвідомому самовизначенні її інтелігібельного характеру.

Своїми теоретичними побудовами Шеллінг ніби відповідає на складні питання, на зразок того, чому страждають діти. Свідома воля дорослої людини не дорівнює незрілій волі немовлят, проте зло діє і в них.

Філософські ідеї Шеллінга позначені спадщиною католицької теології, що бере свій початок від Августина, а саме, від вчення про гріхи, які успадковуються. Гріхопадіння за Августином було не просто особистим гріхом Адама і Єви, але це був момент, коли люди набули свого природного стану, втративши Божественну благодать, тобто спочатку люди перебували у надприродному стані. Для Шеллінга, як спадкоємця західної теології, природа людини виступає в чистому вигляді, тобто такою, якою вона повинна бути сама по собі. Вона не пошкоджена, як це ми бачимо в православній теології, а просто існує як хаос, без Божественної благодаті. Звідси витікає і розуміння дії зла в людині не як продукту пошкодженої природи, а через неї волі і особистості, а як безблагодатного існування індивіду. До речі, М. Бердяєв, який був 
прихильником теодицеї Шеллінга, теж поділяв точку зору Августина на проблему гріхопадіння людини.

Православний богослов В.М. Лур'є писав: «3 точки зору Августина, так званий первородний гріх, що притаманний кожній людині, робить iï із самого початку приреченою на загибель, і тільки особлива милість Божа - „благодать“ - звільняє деяких людей від вічної загибелі, Східна ж Церква ніколи не схвалювала подібних ідей» [7, с. 199].

Отже філософська теодицея Шеллінга продовжує католицьку і, навіть, протестантську богословську там, де справа торкається теоретичних джерел вчення про природу, свободу і особистість людини. До того ж, Шеллінг встановлює поняття природженого зла і добра, що нагадує ідею Кальвіна про моральну приреченість. Тому для німецького філософа питання про страждання безвинних дітей має відповідь, але водночас втрачається свобода особистості в моральному виборі. Християнська ж теологія, особливо православна, навпаки, залишає за людиною абсолютну свободу, вбачає в Богові абсолютне добро, не маючи задовільних відповідей на складні етичні питання.

Ставка Шеллінга на темну природу у Бога вирішує деякі складні питання етики, але відбирає головне-абсолютність добра, віру в свободу людини. Концепція німецького філософа хоча і успадковує релігійну основу, але все ж таки страждає значним недоліком, а саме - існує поза межами християнського розуміння абсолютної благості Творця, тобто - за межами релігійної системи. Питання ж зла може мати місце лише в межах релігійного світосприйняття. У протилежному випадку зло релятивізується і перетворюється на холодний факт, на природну необхідність, що ми і спостерігаємо у Шеллінга.

Таким чином, пояснення та означення зла суперечить самому визначенню зла. Але ж по відношенню до чого ми могли б визначати і позиціонувати зло? Очевидно, що добро і зло не просто є антагоністичними по відношенню один до одного, але й що існує деякий фокус, дещо третє, що опосередковує їх відношення. Цим фокусом повинен бути моральний абсолют, який повинен бути дійсно абсолютним i, в цьому сенсі, - не повинен мати ніякого відношення до зла. Між тим, ми бачимо, що реалізувати грандіозний проект теодицеї неможливо ані в межах теології, ані в межах філософії.

Зло неможливо визначити, одночасно не виправдовуючи його. Але й сказати, що зла немає, неможливо з моральної точки зору. В той же час зло існує тільки по відношенню до морального абсолюту і тільки зі своїм антагоністом - добром. Проте моральний абсолют неможливо виправдати, не виправдовуючи при цьому зла. Це глухий кут. Глухий 
кут не тільки для теодицеї, але й для абсолютистської моралі. Вибір постає не тільки між вірою і безвір'ям, але й між філософією і теологією.

\section{Бібліографія}

[1] Apeonaгum Дионисий. О Божественных именах. Глава четвертая [Електронний ресурс]. - Режим доступу: <http: //www.hesychasm.ru/library/dar/tname.htm. Дата звернення: 11.10.2010.>

[2] Бердяев Н. Философия свободного духа. Часть первая. Глава V [Електронний ресурс]. - Режим доступу: <http://www.i-u.ru/biblio/archive/berdaev_filosofija_svobodnogo $>$. Дата звернення: 11.10.2010.

[3] Булгаков C.Н. Свет невечерний: Созерцания и умозрения. - СПб.: Изд-во Олега Абышко, 2008.

[4] Василий Великий. Беседы на Шестоднев. Беседа 2-я [Електронний ресурс]. - Режим доступу: <http://www.orthlib.ru/ Basil/sixday.html. Дата звернення: 12.10.2010>.

[5] Игумен Иларион (Алфеев). Таинство веры. Введение в православное догматическое богословие [Електронний ресурс].Режим доступу: <http://azbyka.ru/ hristianstvo/dogmaty/ alfeev_tainstvo_veru>. Дата звернення: 10.10.2010.

[6] Лейбнии Г.В. Опыты теодицеи о благости Божией // Лейбниц Г.В. Соч. в 4 т. - Т.4. - М.: Мысль, 1989.

[7] Луръе В.М. История Византийской философии.-M.: Axioma, 2006.

[8] Шеллинг Ф.В.И. Философские исследования о сущности человеческой свободы // Шеллиг Ф.В.И. Соч. в 2 т. - Т.2- М.: Мысль, 1989.

Надійшла до редакиії 23 листопада 2010 р. 